\title{
Fizinio aktyvumo, medikamentinio gydymo, maisto papildų ir kognityvinių treniruočių ịtaka Alzheimerio ligos, susijusių demencijų prevencijai ir kognityvinių gebẻjimų išlaikymui
}

\author{
G. Navickaitė \\ Vilniaus universitetas, \\ Medicinos fakultetas
}

\begin{abstract}
Santrauka. Dèl senėjančios visuomenès, Alzheimerio liga ir susijusios demencijos tampa vis rimtesne problema. Iki šiol nėra atrastų nei efektyvių gydymo metodų, nei veiksnių, galinčių sumažinti tikimybę susirgti šiomis ligomis. Viešai diskutuojama apie galimą fizinio aktyvumo, vaistų, maisto papildų ar kognityvinių treniruočių naudą kognityviniams žmogaus gebejjimams. Tačiau šių metodų nauda nėra įrodyta susijusiais tyrimais. Šio straipsnio tikslas - apžvelgti šių keturių sričių atliktų sisteminių analizių rezultatus, vertinant minètų metodų efektą Alzheimerio ligos, susijusių demencijų ir lengvo kognityvinio sutrikimo prevencijai.
\end{abstract}

Raktažodžiai: Alzheimerio liga, demencija, lengvas kognityvinis sutrikimas, fizinis aktyvumas, medikamentinis gydymas, maisto papildai, kognityvinės treniruotės.

\section{IVADAS}

Daugiau nei 40 milijonų žmonių visame pasaulyje serga Alzheimerio liga (AL) ar kitomis demencijų formomis [1]. AL ir susijusios demencijos (angl. Alzheimer disease and related dementias, ADRD) itin pablogina sergančiųjų gyvenimo kokybę ir sukuria papildomą naštą bei rūpesčius sergančiojo artimiesiems. Dažnai asmenys, sergantys demencija, yra paliekami specifinių slaugos institucijų priežiūrai. JAV demenciją turinčių asmenų priežiūros išlaidos viršija širdies ligų ar vėžio gydymo išlaidas, kurias dažniausiai patiria jų artimieji [2]. Dabartinėmis prognozėmis, iki 2050 m. žmonių, turinčių demenciją ar sergančių AL, gali patrigubėti [3]. Dažniausia demencijos priežastis Alzheimerio liga, tačiau diferencijuoti, ar demenciją sukèlè vien tik AL, ar prisidejo ir kiti demenciją sukeliantys faktoriai, beveik neịmanoma. Dažnai prieš išsivystant demencijai, pacientai turi įgiję lengvą kognityvinị sutrikimą

\author{
Adresas: \\ Gintare Navickaité \\ Vilniaus universitetas, Medicinos fakultetas, \\ M. K. Čiurlionio g. 21, LT-03101 Vilnius \\ El.paštas navickaitegintare@yahoo.com
}

(angl. mild cognitive impairment, MCI) [4]. Taigi, ieškoti efektyvių prevencijos priemonių nuo AL ir kitų demencijų rūšių yra vienas pagrindinių tikslų, norint užkirsti masišką šių susirgimų plitimą ateityje.

Yra kelios pagrindinès sritys, ị kurias dedamos didelès viltys, siekiant užkirsti kelią AL ir kitoms demencijoms tai fizinis aktyvumas, medikamentinis gydymas, maisto papildai ir kognityvinès treniruotès.

\section{FIZINIS AKTYVUMAS}

Daugelis tiki, kad fizinis aktyvumas mažina demencijos ir kognityvinių gebėjimų blogejjimo tikimybę. Vis dèlto, ryšys tarp fizinio aktyvumo ir demencijos prevencijos nèra tiesioginis - fizinis aktyvumas mažina nutukimo, diabeto ar hipertenzijos galimybę, o šie veiksniai turi tiesioginę įtaką ADRD.

Brasure ir kolegų atlikta sisteminé fizinio aktyvumo ir ADRD prevencijos klinikinių tyrimų analizė nagrinėja 16 klinikinių tyrimų, atliktų 2009-2017 m. [5]. Remiantis nagrinejjamais tyrimais, sisteminėje analizèje išskiriamos dvi galimos fizinio aktyvumo grupès: fizinis aktyvumas,

(C) Neurologijos seminarai, 2018. Open Access. This article is distributed under the terms of the Creative Commons Attribution 4.0 International License CC-BY 4.0 (http://creativecommons.org/licenses/by/4.0/), which permits unrestricted use, distribution, and reproduction in any medium, provided you give appropriate credit to the original author(s) and the source, provide a link to the Creative Commons license, and indicate if changes were made. 
neįtraukiant papildomų veiksnių, ir fizinio aktyvumo nauda kartu su kitais veiksniais. Fizinis aktyvumas skirstomas ị daugiakomponentị fizinị aktyvumą, aerobinị aktyvumą, jègos pasipriešinimo treniruotes ir tai či. Fizinị aktyvumą papildantys veiksniai buvo sveika mityba ir kognityvinès treniruotès [5].

Iš 16 atrinktų tyrimų, 4 tyrimai $(n=1885)$ siekė nustatyti daugiakomponenčio fizinio aktyvumo naudą, siekiant užkirsti kelią ADRD [6-9]. Klinikiniai tyrimai truko nuo 6 mėnesių iki 2 metų, o tyrimo dalyviai dalyvavo lankstumo, jègos, pusiausvyros, ištvermès ir aerobinèse treniruotėse. Didžiausiame iš 4 tyrimų $(n=1635)$ po dvejų metų nerasta reikšmingų skirtumų tarp tiriamosios ir kontrolinės grupių galimybės susirgti demencija ar igyti MCI. Vertinant šių 4 tyrimų rezultatus, atlikti 25 palyginimai, iš kurių tik 3 parodè statistiškai reikšmingą daugiakomponenčio fizinio aktyvumo įtaką mažinant tikimybę susirgti ADRD.

Kiti 6 tyrimai $(n=531)$ buvo atlikti siekiant icvertinti aerobinių treniruočių veiksmingumą ADRD prevencijai [10-15]. Vienas tyrimas $(n=170)$ nustaté, kad, praejus 18 mėnesių nuo tyrimo pabaigos, tų asmenų, kurie aktyviai dalyvavo aerobinèse treniruotèse, tikimybè susirgti demencija buvo sumažejusi, lyginant su kontroline tyrimo grupe. Tačiau iš visų 35 rezultatų, gautų iš šių 6 tyrimų, tik 11 rezultatų buvo statistiškai reikšmingi ir rodẻ teigiamą itaką, lyginant su kontroline grupe. Trys tyrimai $(\mathrm{n}=315)$ tyrè jègos pasipriešinimo treniruočių efektyvumą, siekiant sustabdyti kognityvinių gebejjimų pablogèjimą [16-18]. Nè vienas iš trijų tyrimų neparodė reikšmingų rezultatų. Vienas tyrimas $(n=93)$ lygino rezultatus, kai vieni tyrimo dalyviai dalyvavo tai či treniruotėse, o kontrolinès grupès dalyviai nebuvo fiziškai aktyvūs, tačiau šio tyrimo rezultatai nebuvo vienareikšmiškai teigiami [8].

Tyrimų metu, kuriuose fizinis aktyvumas buvo derinamas su tinkama mityba (du tyrimai, $\mathrm{n}=79$ ), dalyviai buvo lyginami su kontroline grupe $[6,19]$. Vienas tyrimas sujungè tinkamą mitybą su 90 minučių daugiakomponentèmis fizinėmis treniruotemis tris kartus per savaitę, vienerius metus. Kitas tyrimas sujungė tinkamą mitybą ir grupines aerobines treniruotes ir truko 6 mènesius. Nè vieno tyrimo rezultatai nebuvo statistiškai reikšmingi. Van de Rest su kolegomis išanalizavo du tyrimus, kurių metu dalyviams buvo paskirtas fizinis aktyvumas ir maisto papildai, turintys baltymų [20, 21]. Abu tyrimai truko po 24 savaites. Tik vienas iš 11 dèmesio koncentraciją ir informacijos apdorojimą vertinančių kognityvinių testų ir nė vienas iš 6 atmintị vertinančių kognityvinių testų nustate statistiškai reikšmingą teigiamą efektą, lyginant su kontroline grupe. Vienas tyrimas $(n=134)$ kontrolinę grupę lygino su grupe, dalyvaujančia struktūruotuose muzikiniuose užsièmimuose, kuriuose derintas fizinis aktyvumas ir kognityvinių gebejjimų treniravimas, remiantis muzikos intensyvumu [22]. Tyrimo metu šešis mėnesius dalyviai lankydavo vieną 60 minučių treniruotę per savaitę. Šio, kaip ir ankstesnių tyrimų, rezultatai, siekiant ịrodyti naudą išvengiant ADRD, buvo statistiškai nereikšmingi.

Paskutinis klinikiniais tyrimais nagrinètas fizinio aktyvumo būdas - fizinio aktyvumo, sveikos mitybos ir kogni- tyvinių treniruočių derinimas. FINGER (angl. Finnish Geriatric Intervention Study to Prevent Cognitive Impairment and Disability) tyrime $(\mathrm{n}=1260)$ lygintos kontrolinè grupè ir grupè, kuriai pritaikyta ADRD prevencinè programa, ic kurią iejo asmeninio mitybos plano sudarymas, nuo 1 iki 3 aerobinių treniruočių per savaitę, nuo 2 iki 5 jègos pasipriešinimo treniruočių per savaitę ir grupinių bei individualių kognityvinių gebejjimų gerinimo treniruočių [23]. Tyrimo trukmé - dveji metai. Po dvejų metų tyrimo dalyvių neuropsichologinių testų rezultatai buvo $25 \%$ geresni nei kontrolinės grupès. Vertinant kontrolinès grupės ir aktyvių tyrimo dalyvių atmintị, statistiškai reikšmingo skirtumo nerasta.

Remiantis Brasure su kolegomis atlikta sistemine analize [5], vien fizinio aktyvumo taikymas ADRD prevencijai nėra efektyvus. Vienintelis tyrimas, kurio teigiamiems rezultatams pakako duomenų ir įrodymų, yra FINGER tyrimas. Jo metu fizinis aktyvumas, tinkama mityba ir kognityvinès treniruotės taikytos kompleksiškai, siekiant užkirsti kelią keliems rizikos veiksniams iš karto (ADRD, širdies ir kraujagyslių ligoms, nutukimui, diabetui). Nagrinėtiems tyrimams, kurių metu ADRD prevencijai taikytas tik fizinis aktyvumas, trūksta ịrodymų dèl tiesioginès ịtakos kognityviniams gebejjimams [5]. Tačiau tai neįrodo, kad vien tik fizinis aktyvumas nèra efektyvi ADRD prevencijos priemonè - atlikti tyrimai nebuvo pakankamai ilgi ar pakankamai svarūs, siekiant įvertinti tikrą fizinio aktyvumo naudą. Fizinis aktyvumas gali sumažinti riziką susirgti ADRD tiek tiesiogiai (pagerina kraujotaką), tiek netiesiogiai (veikdamas kitus ADRD skatinančius rizikos faktorius, tokius kaip širdies ir kraujagyslių ligos, nutukimas, diabetas). Nagrinėtuose tyrimuose dauguma dalyviu tapo fiziškai aktyvūs po daugybès metų fiziškai neaktyvaus gyvenimo būdo, taigi mažai tikètina, kad tai efektyviai apsaugotu nuo ADRD ir MCI. Taip pat sunku lyginti rezultatus dèl nevienodos tyrimų trukmès, dalyvių skaičiaus, stipriai kintančio fizinio krūvio ir sudètingo kognityvinių gebejjimų vertinimo dèl skirtingų testų ir skalių. Siekiant išsiaiškinti, ar fizinis aktyvumas yra efektyvi prevencijos priemonė, tai turètų gana anksti tapti žmogaus gyvenimo būdo dalimi. Ateities tyrimai galètų koncentruotis ì asmenis, kurie fizinị aktyvumą pavertè savo gyvenimo dalimi, ir ilgesnị laiką stebėti, ar šis fizinis aktyvumas turi teigiamos įtakos kognityviniams gebejjimams. Remiantis nagrinètais tyrimais, fizinis aktyvumas vyresnio amžiaus žmonėms gali būti efektyvi prevencijos priemonė, siekiant išvengti ADRD, tik jei jis inkorporuojamas kartu su kitais veiksniais (sveika mityba ir kognityvinemis treniruotèmis), kaip ir buvo parodyta FINGER tyrime. Išvadų, kad vien fizinis aktyvumas yra efektyvi prevencinė ADRD priemonè, negalima daryti dèl ịrodymų trūkumo.

\section{MEDIKAMENTINIS GYDYMAS}

Kartu su fiziniu aktyvumu, kitas dažnai ịvardijamas prevencinis demencijų, AL ir lengvo kognityvinio sutrikimo gydymas yra farmakologinis (medikamentinis). Apžvel- 
giamas 51 klinikinis tyrimas, kurio metu buvo bandoma įsitikinti specifinio medikamentinio gydymo efektyvumu bei saugumu siekiant užkirsti kelią ADRD [24]. Dalis iš 51 atrinkto tyrimo pašalinta dẻl didelès šališkų rezultatų tikimybès. Medikamentinis gydymas taikytas tiek normaliu kognityvinių gebėjimų dalyviams, tiek dalyviams su lengvu kognityviniu sutrikimu. Klinikinių tyrimų medikamentinį gydymą ADRD prevencijai sudarè vaistai demencijai, hipertenzijai ir cukriniam diabetui gydyti, cholesterolio koncentraciją mažinantys vaistai, nesteroidiniai priešuždegiminiai vaistai (NVNU) ir hormonų terapija.

Tyrimuose, kuriuose taikyti vaistai demencijai gydyti, rasta, kad dalyviai, turintys MCI ir gavę acetilcholinesterazès inhibitorių, rodè tokius pat rezultatus, kaip ir dalyviai, turintys MCI, bet gavę placebą. Didžioji dalis išvadų gauta tyrime $[25,26]$, kurio dalyviams $(n=512)$ atsitiktiniu būdu buvo paskirtas donepezilis arba placebas. Visgi, po trejus metus trukusio tyrimo nebuvo rasta statistiškai reikšmingu skirtumų tarp abiejų tyrimo grupių kognityvinių gebejjimų ar AL progresavimo. Rasta, kad tų dalyvių, kurie turejjo mažiausiai 1 apolipoproteino e4 alelị ir vartojo donepezili, būklè rečiau progresuodavo ị Alzheimerio ligą nei tų, kurie vartojo placebą. Galiausiai nustatyta, kad ši išvada statistiškai nereikšminga. Vienintelès tikslios išvados - dalyviai, vartoję donepezili, dažniau kentejo nuo šalutinio poveikio, kaip skrandžio veiklos sutrikimai, miego sutrikimai ar artritas [24].

Kita tyrimų grupė tyrẻ galimą vaistų nuo hipertenzijos naudą, siekiant išvengti ADRD. 8 unikaliuose tyrimuose ( $\mathrm{n}=31287$ ) ieškota skirtumų tarp kontrolinès grupès, vartojančios placebą, ir grupès, vartojančios vaistus nuo hipertenzijos. Nustatyta, kad asmenims, dalyvavusiems tyrime ir turintiems normalius kognityvinius gebejjimus, antihipertenzinis gydymas, palyginti su kontroline placebo grupe, nesumažina demencijų pavojaus. Taip pat nerasta jokio skirtumo tarp abiejų grupių rezultatų, atlikus kognityvinių gebėjimų vertinimo testus. Kitas tyrimas ( $n=1439$, vidutinis dalyvių amžius - 62,4 metų) siekè išsiaiškinti standartinio ir intensyvaus antihipertenzinio gydymo naudą ADRD prevencijai [27]. Dalyviai nesirgo ADRD ir neturejo MCI, sirgo diabetu ir turejo padidèjusią kardiovaskulinių ligų riziką. Dviejų tyrimo grupių dalyviai turèjo 40 mėnesių palaikyti mažesnị nei $120 \mathrm{mmHg}$ ir mažesnị nei $140 \mathrm{mmHg}$ sistolinị kraujo spaudimą, vartodami antihipertenzinius vaistus. Pasibaigus tyrimui, skirtumų tarp abiejų grupių, vertinant ADRD susirgimus ir igytą lengvą kognityvini sutrikimą, nerasta. Dar 9 tyrimuose $(n=28$ 933) siekta išsiaiškinti antihipertenzinių vaistų itaką ADRD prevencijai, lyginant skirtingus vaistus. Tyrimų išvados parodè, kad skirtingi antihipertenziniai vaistai neturėjo įtakos dalyvių kognityvinių testų rezultatams. Didžiausias iš šių tyrimų - ONTARGET (angl. Ongoing Telmisartan Alone and in Combination with Ramipril Global Endpoint Trial), kuriame dalyvavo 25620 pacientų, nerado statistiškai reikšmingų skirtumų tarp tiriamujų grupių, vertinant ADRD riziką. Tyrimai neatskleidè jokio galimo antihipertenzinių vaistų vartojimo teigiamo poveikio ADRD prevencijai [24].
Keturiuose tyrimuose siekta nustatyti galimą cukriniam diabetui gydyti skirtų vaistų efektą, vertinant jų naudą ADRD prevencijai [24]. Didžioji dalis rezultatų gauti iš dviejų pagrindinių tyrimų, ACCORD-MIND (angl. Action to Control Cardiovascular Risk in Diabetes-Memory in Diabetes) [28, 29] ir ORIGIN (angl. Outcome Reduction with Initial Glargine Intervention) [30]. Bendras šių dviejų tyrimų dalyvių skaičius - 14 662. Tyrimo dalyviai buvo suskirstyti ị dvi grupes, kurioms paskirtas skirtingo intensyvumo vaistas cukriniam diabetui gydyti (intensyvesni gydymo kursą gavusi grupè stebėta 3,3 metų, o standartini gydymo kursą - 6,2 metų). Vertinant šių tyrimų rezultatus, nepakanka įrodymų ryšiui tarp skirtingo intensyvumo vaistų cukriniam diabetui gydyti ir ADRD prevencijos įrodyti. ORIGIN tyrimas nerado skirtumų tarp grupių, atsižvelgiant į ADRD sergamumą, o vertinant abiejų tyrimų dalyvių kognityvinių testų rezultatus prieita prie vienodos išvados - reikšmingų skirtumų nerasta [31, 32].

7 tyrimuose $(n=23097)$ buvo nagrinèta cholesterolio koncentraciją mažinančių vaistų ịtaka ADRD sergamumui ir prevencijai. Šie tyrimai nepateikè pakankamai duomenų, kad būtų ịrodytos HMG-KoA reduktazès inhibitorių demencijos ar MCI prevencinės savybès. Didžiausias tyrimas ( $\mathrm{n}=20536$ ) suskirstè dalyvius ị dvi grupes ir penkerius metus vienai iš grupių skyrė kasdien vartoti $40 \mathrm{mg}$ simvastatino, o kitai - placebą. Šiame tyrime taip pat negauta reikšmingų skirtumų tarp dviejų tiriamųjų grupių vertinant ADRD prevenciją, susirgimus ar kognityvinių testų rezultatus. Atskiras tyrimas $(n=503)$ lygino rezultatus grupių, kurių vienai skirtas medikamentinis gydymas statinais ir fenofibratu, o kitai - gydymas vien statinais. Tyrimo išvadose teigiama, kad reikšmingo skirtumo, lyginant abiejų grupių kognityvinių testų rezultatus, nerasta [27].

Dviejuose klinikiniuose tyrimuose tirta nesteroidinių priešuždegiminių vaistų (NVNU) įtaka, siekiant užkirsti kelią Alzheimerio ligai ir susijusioms demencijoms. Tyrimuose dalyvavo vyresnio amžiaus žmonès, turintys normalius kognityvinius gebejjimus. Remiantis abiejų tyrimų išvadomis, nei NVNU, nei aspirinas neturi įtakos ADRD rizikos mažinimui ar kognityvinių testų rezultatams. ADAPT (angl. Alzheimer's Disease Anti-Inflammatory Prevention Trial) tyrime dalyvavo 2528 žmonès (vidutinis amžius - 74 metai). Jie buvo suskirstyti ị tris grupes, kurių dalyviai vartojo naprokseną, celekoksibą arba placebą [33]. Po vidutiniškai 15 mėnesių tyrimo dalyviams buvo atskleista, kuriai grupei jie priklauso. ADAPT tyrimas parodè, kad, vertinant demencijų sergamumą (tikrinta 8 metai nuo tyrimo pradžios) ir kognityvinių gebejjimų testų rezultatus (testai atlikti po 4 metų nuo tyrimo pradžios), nėra reikšmingo skirtumo tarp grupès, gavusios placebą, ir kitu dviejų grupių, vartojusių vieną iš NVNU. Vis dẻlto, tyrimo dalyviai, vartoję kurị nors iš dviejų NVNU, turejjo daug didesnę riziką susirgti hipertenzija [34]. Rezultatai apie aspirino itaką ADRD yra gauti iš Moteru sveikatos tyrimo (angl. Women's Health Study) subtyrimo, kurio metu 6377 dalyviams buvo paskirta maža aspirino dozė arba placebas [35]. 
Daugiausia tyrimų atlikta siekiant ištirti hormoninès terapijos pritaikymą ADRD prevencijai. Hormoninès terapijos tyrimai suskirstyti ị estrogenų terapiją, estrogenų ir progesterono terapiją, selektyvių estrogenų receptorių moduliatorių terapiją ir testosterono terapiją. 6 tyrimai nagrinejo estrogeno poveiki ADRD. Bendra visų tyrimų išvada: estrogenų hormoninè terapija paskatino MCI ir demencijų vystymąsi, tačiau neturi jokios įtakos kognityvinių testų rezultatams. Tyrimuose dalyvavo moterys, turinčios normalius kognityvinius gebejjimus. Daugiausia informacijos gauta iš WHIMS (angl. Women's Health Initiative Memory Study) tyrimo ( $\mathrm{n}=2$ 947), kuriame dalyvavo moterys nuo 65 metų amžiaus. Tyrimo dalyvėms atsitiktine tvarka paskirtas estrogenas arba placebas, kurị jos vartojo vidutiniškai 5,2 metų. Rezultatai patvirtino padidejjusią riziką susirgti ir MCI, ir ADRD kartu, bet ne atskirai.

5 tyrimai nagrinejo estrogeno ir progesterono poveiki ADRD. Kaip ir tyrimuose, kuriuose vartotas tik estrogenas, estrogeno ir progesterono hormoninè terapija paskatino tam tikras ADRD, tačiau neturejjo įtakos kognityvinių testų rezultatams. Estrogenas ir progesteronas padidino riziką susirgti demencija. Tyrimuose dalyvavo moterys nuo 65 metų amžiaus, turinčios normalius kognityvinius gebėjimus. 4532 tyrimo dalyvėms vidutiniškai 4,1 metų atsitiktine tvarka buvo paskirta estrogeno ir progesterono terapija arba placebas. Estrogeną ir progesteroną vartojusioms tyrimo dalyvėms labai padidejo rizika susirgti demencija, tačiau tikimybė susirgti MCI arba ir MCI, ir demencija liko nepakitusi.

Du išskirtiniai tyrimai nagrinėjo selektyvių estrogenų receptorių moduliatorių terapijos (raloksifeno) ịtaką ADRD. Tyrimo dalyvėms - vyresnio amžiaus moterims, sergančioms osteoporoze, buvo skirta $60 \mathrm{mg}$ raloksifeno per dieną, $120 \mathrm{mg} / \mathrm{d}$ raloksifeno per dieną arba placebo [36-38]. Rezultatai gauti kaip MORE (angl. Multiple Outcomes of Raloxifene Evaluation) tyrimo subtyrimas [36, 37]. Rasta, kad tyrime dalyvavusios normaliu kognityvinių gebejjimų moterys, gavusios 120 mg raloksifeno kasdien, turejjo mažesnę riziką ịgyti lengvą kognityvinị sutrikimą (MCI), tačiau gydymas neturèjo įtakos tikimybei susirgti ADRD ar MCI ir ADRD kartu. Reikšmingų skirtumų tarp tyrimo dalyvių, gavusių $60 \mathrm{mg}$ raloksifeno dozes ir placebo, nerasta. Trijuose tyrimuose buvo aiškinamasi testosterono ịtaka ADRD sergamumui ir kognityviniams gebejjimams, tiriant vyresnio amžiaus vyrus su žema testosterono koncentracija. Tyrimo dalyviai buvo suskirstyti ị dvi grupes, kurių vienai skirta testosterono terapija, o kitai placebo. Reikšmingų skirtumų tarp dviejų grupių nerasta. Nustatyta, kad vyrams, praejusiems testosterono hormonų kursą, padidejo eritrocitozès tikimybė [39].

Taigi, visi aptarti tyrimai, kurie nagrinejjo ryšį tarp medikamentinio gydymo ir ADRD, padare tris išvadas: a) estrogenų hormonų terapija galimai padidina riziką susirgti MCI ir demencija kartu (bet ne atskirai); b) estrogenų ir progesterono hormonų terapija galimai labai padidina riziką susirgti demencija (bet ne MCI atskirai ar MCI ir demencija kartu); c) gydymas didesne doze raloksifeno (120 mg per dieną) sumažina tikimybę susirgti MCI (bet ne demencija ar MCI ir demencija kartu). Norint gauti tikslesnius rezultatus, tyrimai turètų kuo labiau atitikti optimalius kriterijus: medikamentinio gydymo tyrimas turètų nagrinèti kelis rizikos faktorius tuo pat metu, prasidèti, kai tyrimo dalyvis ịpusėja gyvenimą, tęstis iki gyvenimo pabaigos, nuolat fiksuoti aktualius duomenis ir pokyčius, reguliariai tikrinti kognityvinius dalyvių gebėjimus standartizuotais testais, rezultatus interpretuoti pritaikant visiems tyrimo dalyviams ir iš anksto numatytoms tyrimo dalyvių subgrupèms. Visų minètų sąlygų neįmanoma įgyvendinti dẻl per didelių išlaidų ir sudètingos tyrimo struktūros, tačiau ateities tyrimams rekomenduojama pasistengti orientuotis ị daugiau kriterijų [24].

\section{MAISTO PAPILDAI}

Didèjantis sergamumas AL, taip pat didèjantis MCI ir demencijų skaičius daro reikšmingą ịtaką sparčiai augančiai maisto papildų industrijai. Produktų, galimai mažinančių Alzheimerio ligos ir kognityvinių gebejjimų pablogėjimo riziką, paklausa didėja - 63 \% vyresnio amžiaus žmonių vartoja maisto papildus, galimai gerinančius atmintị ir kognityvinius gebejjimus [40]. Vis dèlto, šių produktų reklamuojamas poveikis nėra įrodytas. Sisteminėje Butler ir kolegų apžvalgoje atrinkti klinikiniai bandymai, vykdyti nuo 2009 iki $2017 \mathrm{~m}$. liepos mènesio [41]. Iš viso atrinki ir susisteminti 38 tyrimai, kurie nagrinėja maisto papildų galimą naudą ADRD prevencijai ir kognityvinių gebėjimų išlaikymui. Tyrimo dalyviai - normalių kognityvinių gebèjimų žmonės arba asmenys, turintys lengvą kognityvinį sutrikimą, bet ne demenciją ir nesergantys AL. Maisto papildai suskirstyti ị omega-3 riebalų rūgštis, soją, ginkmedị, $B$ grupès vitaminus (folio rūgštị, folio rūgštic ir vitaminą $B_{12}$, folio rūgštị kartu su vitaminais $B_{6}$ ir $B_{12}$ ), vitaminą $D$ ir kalcị, vitaminą $\mathrm{C}$ arba $\beta$-karoteną, multivitaminus ir kelių komponentų papildus bei kitus maisto papildus.

7 klinikiniuose tyrimuose $(n=21027)$ tirta omega-3 riebalų rūgščių nauda kognityviniams gebejjimams ir galimybės taikyti ši papildą ADRD prevencijai. Tyrimuose dalyvavo normalius kognityvinius gebėjimus turintys asmenys, kuriems atsitiktiniu būdu buvo skirtos omega-3 riebalų rūgštys arba placebas. Preparatai vartoti nuo 6 mènesių iki 6 metų. Viename iš tyrimų kaip papildas buvo skiriama dokozaheksaeno rūgštis (DHR) [42], likusiuose šešiuose tyrimuose papildas buvo sudarytas kombinuojant eikozapentaeno rūgštį (EPR) su DHR. Bendra visų septynių tyrimų išvada - nerasta pakankamai svarių įrodymų, rodančių teigiamą omega-3 riebalų rūgščių ịtaką dalyvių kognityviniams gebẻjimams. Statistiškai reikšmingų skirtumų kognityvinių testų rezultatuose tarp abiejų grupių nerasta, o iš bendrai atliktų 67 testų (9 trumpi kognityviniai testai; 1 neuropsichologinis testas; 32 testai, tikrinantys dèmesio sutelkimą ir informacijos vertinimo greitic; 25 atminties testai) tik 5 testai rodè daug geresni rezultatą, lyginant EPR ir DHR papildus vartojusias grupes su placebo grupèmis. Tačiau teigiami rezultatai gauti iš dviejų tyrimų, kurie buvo vieni trumpiausių ir kurių dalyviai sudarẻ apie $5 \%$ 
nuo visų minètų 7 tyrimų [42, 43]. Informacijos apie galimą prevencini poveiki tyrimuose nepateikta. Taip pat išnagrinètas vienas papildomas tyrimas, kuriame dalyvavo asmenys, turintys lengvą kognityvinị sutrikimą (MCI) [41]. Tarp dalyvių grupių, kurios metus vartojo arba omega-3 riebalų rūgštis, arba placebą, reikšmingų skirtumų nerasta dèl trumpos tyrimo trukmės ir mažo dalyvių skaičiaus $(\mathrm{n}=36)[44]$.

Penki tyrimai, kurių kiekviename dalyvavo nuo 35 iki 350 dalyvių $(n=829)$ ir truko nuo 6 mènesių iki 2,5 metų, lygino sojos maisto papildų įtaką kognityviniams gebejjimams su placebu. Tyrimuose dalyvavo normalių kognityvinių gebejjimų vyresnio amžiaus asmenys, kurių protinės būklès mini tyrimo (angl. Mini-Mental State Examination, MMSE) rezultatai svyravo nuo 28 iki 29 [45-48]. Tyrimu pabaigoje nefiksuotas nè vienas ADRD ar MCI susirgimas. Nustatyta, kad nepakanka įrodymų spręsti apie sojos maisto papildų itaką trumpų kognityvinių ir neuropsichologinių testų rezultatams. Po 2,5 metų atlikus dèmesio sutelkimą, informacijos vertinimo greitic ir atmintic vertinančius kognityvinius testus, sojos maisto papildai šių testų rezultatams reikšmingos įtakos neturèjo [41]. Ivvertintas ir vienas papildomas tyrimas ( $\mathrm{n}=78)$, kuriame dalyvavo asmenys, turintys lengvą kognityvinį sutrikimą. Dalyviai buvo suskirstyti i tris grupes, kurių kiekviena kasdien vartojo placebą arba 100/300 mg iš sojų pupelių išgautą fosfatidilseriną. Palyginus visų tiriamųjų grupių kognityvinių testų rezultatus po 9 tyrimų mėnesių, reikšmingų skirtumų tarp grupių nerasta [47].

Trijuose tyrimuose $(n=5559)$ siekta rasti galimą dviskiaučio ginkmedžio (ginkgo biloba) teigiamą efektą, gerinant ar palaikant kognityvinius žmogaus gebejjimus. Tyrimų trukmè - iki 6 metų. Dalyviai buvo suskirstyti ị grupes, kurioms skiriamas ginkmedžio ekstraktas (240 mg per dieną), ir placebo grupę [49-52]. Tyrimuose dalyvavo nuo 118 iki 3069 asmenų, kurie pagal amžių buvo suskirstyti i grupes: nuo 70 metų [52], nuo 75 metų $[49,51]$ ir nuo 85 metų [50]. Dviejuose iš trijų tyrimų buvo nustatyta, kad ginkmedžio ekstrakto vartojimas neturèjo įtakos kognityvinių gebėjimų gerinimui ar išlaikymui [49-52]. Reikšmingo skirtumo tarp tyrimo grupių, vertinant kognityvinių gebejjimų rezultatus, nerasta [41]. Papildomame 6 mėnesius trukusiame tyrime $(n=160)$ analogiškai buvo tiriama ginkmedžio teikiama nauda kognityviniams žmonių gebėjimams, tačiau, priešingai nuo ankstesnių trijų tyrimų, dalyviais pasirinkti asmenys, turintys lengvą kognityvinị sutrikimą. Ginkmedžio ekstrakto vartojimas neturèjo įtakos ADRD sergamumui MCI turintiems tyrimo dalyviams, tačiau rastas mažas teigiamas poveikis vertinant dalyvių dèmesio sutelkimą ir informacijos vertinimo greitị [53].

B grupès vitaminų poveikis ADRD, MCI ir kognityviniams žmonių gebejjimams tirtas skaidant $\mathrm{B}$ grupès vitaminų elementus ị šias grupes - folio rūgštic folio rūgštị ir vitaminą $B_{12}$ bei folio rūgšti kartu su vitaminais $B_{6}$ ir $B_{12}$. Vieninteliu klinikiniu tyrimu $(n=818)$ siekta nustatyti folio rūgšties poveikị Alzheimerio ligai, susijusioms demencijoms ir normalių kognityvinių gebejjimų palaikymui [54]. Tyrime dalyvavo normalių kognityvinių gebejjimų asme- nys (vidutinis MMSE vertinimas - 29/30), kuriems trejus metus kasdien buvo skiriama $0,8 \mathrm{mg}$ folio rūgšties arba placebo. Folio rūgšties nauda, vartojant šị maisto papildą ADRD ir MCI prevencijai ir normalių kognityvinių gebejjimų išlaikymui, neįrodyta.

Du klinikiniai tyrimai $(n=3819)$ lygino dalyvių kognityvinių testų rezultatus (dėmesio sutelkimo, informacijos vertinimo greičio ir atminties) po dvejus metus trukusių tyrimų, kurių metu vienai grupei kasdien buvo skiriama $0,4 \mathrm{mg}$ folio rūgšties ir nuo $0,1 \mathrm{iki} 0,5 \mathrm{mg}$ vitamino $B_{12}, \mathrm{o}$ kitai - placebo [55, 56]. Nors tyrimo pabaigoje neužfiksuotas nè vienas susirgimas AL ar MCI, reikšmingo skirtumo tarp grupių, vertinant dèmesio sutelkimo ir informacijos vertinimo greičio testų rezultatus, nerasta. Taip pat nustatyta, kad dalyvių, vartojusių folio rūgštị ir vitaminą $B_{12}$, atminties testų rezultatai buvo šiek tiek geresni nei placebo grupès [41]. Atlikti du tyrimai ( $n=1524)$, siekiant ištirti trijų elementų naudą kognityviniams žmogaus gebejjimams [57, 58]. Normalių kognityvinių gebẻjimų tyrimų dalyviai suskirstyti į dvi grupes, kurios nuo 2 iki 4 metų kasdien vartojo placebą arba folio rūgšti (nuo 0,56 iki 1,0 mg), vitaminą $B_{6}$ (nuo 3 iki $10 \mathrm{mg}$ ) ir vitaminą $B_{12}$ (nuo 0,2 iki $0,5 \mathrm{mg}$ ). Tyrimų rezultatai neparodė reikšmingo skirtumo, vertinant dalyvių trumpų kognityvinių ar atminties testų rezultatus. İrodymų, norint daryti prielaidas apie folio rūgšties, vitamino $B_{6}$ ir vitamino $B_{12}$ efektą dalyvių dèmesio sutelkimui ir informacijos vertinimo greičiui, nepakako. Dar vienas papildomas tyrimas $(n=217)$ tyrẻ folio rūgšties, vitamino $B_{6}$ ir vitamino $B_{12}$ efektą, tačiau šio tyrimo dalyviai turejjo lengvą kognityvinị sutrikimą. Statistiškai reikšmingų skirtumų, vertinant dalyvių kognityvinių gebẻjimų pokyčius tarp grupių, nerasta; tiksliam tyrimo rezultatų interpretavimui trukdè ir maža imtis (mažiau nei 500 dalyvių) [59-62].

Vienas tyrimas $(n=4143)$ aiškinosi galimą vitamino $D$ ir kalcio teigiamą efektą MCI bei ADRD prevencijai. Dvi dalyvių grupès kasdien vartojo $0,01 \mathrm{mg}$ vitamino $\mathrm{D}_{3}$ ir $1000 \mathrm{mg}$ kalcio arba placebą [63]. Tyrimas truko vidutiniškai 7,8 metų, o dalyviai, kuriems buvo paskirta vartoti vitaminą $\mathrm{D}_{3}$ ir kalci, savo noru papildomai galejjo vartoti iki $600 \mathrm{mg}$ vitamino D ir $1000 \mathrm{mg}$ kalcio kasdien. Tyrimo rezultatai neparodè statistiškai reikšmingo skirtumo tarp grupių, vertinant riziką susirgti ADRD ar MCI [41].

Trys tyrimai ( $\mathrm{n}=12830)$, kurių trukmè - nuo 9 iki 10 metų, tyrẻ galimą vitamino Eįtaką ADRD sergamumui, kasdien vartojant nuo $270 \mathrm{iki} 400 \mathrm{mg}$. Tyrimuose dalyvavo normalių kognityvinių gebejjimų vyrai [64] ir moterys [65, 66]. Tyrime, kuriame dalyvavo vyrai, nustatyta, kad, lyginant su placebo grupe, vitamino E vartojimas nedare jokios įtakos tikimybei susirgti demencija. Likusių dviejų tyrimų rezultatai neparodè reikšmingo skirtumo tarp grupių, vertinant dalyvių trumpų kognityvinių testų, neuropsichologinių testų ar atminties testų rezultatus. Vieno papildomo tyrimo metu ( $\mathrm{n}=516$, dalyviai, turintys $\mathrm{MCI}$ ) nustatyta, kad dalyviams, 3 metus kasdien vartojusiems 2000 TV vitamino E [25], ir dalyviams, tą patị laikotarpị vartojusiems placebą, tikimybė susirgti ADRD nesiskyrè.

Viename tyrime $(n=2824)$ siekta rasti ryši tarp kasdienio vitamino $C$ ir $\beta$-karoteno vartojimo bei kognityviniu 
gebejjimų kitimo. Dalyviams buvo paskirta kasdien vartoti $500 \mathrm{mg}$ vitamino $\mathrm{C}, 50 \mathrm{mg} \beta$-karoteno arba placebą [65]. Nors tyrimas truko devynerius metus, pagrindiniai rezultatai buvo gauti po ketverių metų nuo tyrimo pradžios. Tyrimo rezultatai nerodẻ reikšmingų skirtumų tarp visų trijų grupių, vertinant jų trumpų kognityvinių testų, neuropsichologinių testų ir atminties testų rezultatus.

Dar viena tirta maisto papildų kategorija ir jos efektas ADRD, MCI ir kognityviniams gebejjimams - multivitaminai. Keturi tyrimai $(n=27613$, dalyviai yra normaliu kognityvinių gebėjimų) vertino kognityvinius gebẻjimus ir sergamumą ADRD bei MCI, lygindami dalyvių grupes, vartojusias multivitaminus, su grupèmis, vartojusiomis placebą [67-70]. Nagrinejjamuose keturiuose tyrimuose dalyvių grupès vartojo multivitaminus skirtingomis dozèmis ir šių medžiagų kombinacijomis: vitaminus A, B, C, D, ir E, $\beta$-karoteną, biotiną, kobalaminą, varị, folio rūgštį, jodą, geležị, magnị, manganą, niaciną, pantoteno rūgštic, piridoksiną, riboflaviną, seleną, tiaminą ir cinką. Tyrimų dalyvių skaičius svyravo nuo 1130 iki 20 536, trukmè - nuo 6 mènesių iki 8,5 metų. Didžiausio tyrimo $(n=20536)$ išvadose teigiama, kad, pasibaigus tyrimui, statistiškai reikšmingo skirtumo tarp dviejų grupių, vertinant ADRD ir MCI sergamumą, nerasta [68]. Vertinant kognityviniu gebejjimų testų (neuropsichologinio testo, testų, tikrinančių dèmesio sutelkimą ir informacijos vertinimo greiti, ir atminties testo) rezultatus, tarp abiejų grupių reikšmingu skirtumų nerasta [41]. Papildomo tyrimo $(n=256$, dalyviai, turintys lengvą kognityvinị sutrikimą) įrodymai buvo nepakankami, siekiant įvertinti vitamino E (300 mg kasdien) ir vitamino C (400 mg kasdien) įtaką asmenų, turinčių MCI, kognityviniams gebẻjimams po vienerių metu [71]. Po vieną tyrimą atlikta, siekiant ịrodyti ryši tarp kognityvinių gebejimų ir dehidroepiandrosterono, raudonųjų dobilų, resveratrolio ar augalinių sterolių ir stanolių vartojimo, tačiau dẻl mažos imties ir mažo kiekio tyrimų nepakanka rezultatų ryšiui įrodyti [41].

Nagrinėtuose tyrimuose apžvelgta gana maža pasiūloje esančių maisto papildų, galimai gerinančių ar palaikančių kognityvinius gebejjimus, dalis. Dauguma minètų tyrimų siekè išsiaiškinti ryši tarp maisto papildo vartojimo ir kognityvinių gebẻjimų testų rezultatų, bet ne maisto papildų taikymo ADRD ir lengvo kognityvinio sutrikimo prevencijai, be to, tik maža dalis tyrimų ịtraukè asmenis, turinčius lengvą kognityvinị sutrikimą. Apibendrinant nagrinètų tyrimų rezultatus, minètų maisto papildų nauda, siekiant palaikyti ar pagerinti kognityvinius gebejjimus, yra labai menka arba jos apskritai nėra. Nèra pakankamai ịrodymų, kad plačiai reklamuojami maisto papildai, galimai gerinantys ar palaikantys kognityvinius gebejjimus, galètų būti rekomenduojami.

\section{KOGNITYVINĖS TRENIRUOTĖS}

Analogišką maisto papildų industrijai augimą šiuo metu išgyvena ir kognityvinių treniruočių sritis. Kognityvinės treniruotės pirkejjams žada išlaikyti esamus kognityvinius ge- bẻjimus arba juos pagerinti. Tačiau nèra iki galo įrodyta, ar kognityvinès treniruotės tikrai duoda teigiamą efektą kognityviniams žmonių gebejjimams ir ar gali būti naudojamos ADRD ir MCI prevencijai. Iš 35 identifikuotų klinikinių bandymų, remiantis šališkumo kriterijumi, atrinkta 11 tyrimų, iš kurių 6-iuose dalyvavo normalių kognityvinių gebẻjimų asmenys, o likusiuose 5 tyrimuose - dalyviai, turintys lengvą kognityvini sutrikimą [72].

Tyrimuose, kuriuose dalyvavo normalių kognityvinių gebejjimų asmenys, dalyvių skaičius svyravo nuo 40 iki 2 832, o kognityvinès treniruotės buvo vykdomos nuo 2 savaičių iki 6 mėnesių. Trys tyrimai treniruotėms naudojo vien kompiuterius [73-75], 2 tyrimuose pasitelkti tiek kompiuteriai, tiek nekompiuterinės mokymo priemonès $[76,77]$, o viename tyrime vykdyti grupiniai užsièmimai [78]. Didžiausias iš 6 tyrimų $(n=2832)$ - ACTIVE, suskirstė dalyvius (vidutinis amžius - 74 metai) į 4 grupes. 3 tyrimo dalyvių grupès gavo aktyvias kognityvines treniruotes atminties, mąstymo arba informacijos apdorojimo greičio srityje, o paskutinė grupė buvo palikta kontrolei [76]. Iš viso dalyviams skirta per 6 savaites 10 treniruočių po 60-70 minučių. Dalyviai buvo testuojami tik toje kognityvinejje srityje, kurios treniruotèse jie dalyvavo. Vertinant tyrimo rezultatus, nustatyta, kad asmenų, dalyvavusių kognityvinèse treniruotèse, rezultatai pagerejjo, lyginant su kontroline grupe, tačiau tik toje srityje, kuri buvo priskirta. Irodymų apie šiame tyrime pasitelktų kognityvinių treniruočių įtaką ADRD ir MCI prevencijai nerasta.

IHAMS tyrime (angl. the Iowa Healthy and Active Minds Study) (n = 681) dalyviai buvo suskirstyti pagal amžių (grupè nuo 50 iki 64 metų ir grupè, kuriems per 65 metus) ir jiems paskirtos specifinès kognityvinès treniruotès: kognityvinès vaizdinės informacijos apdorojimo treniruotės mokymo centre, kognityvinès vaizdinès informacijos apdorojimo treniruotès dalyvių namų kompiuteriuose arba kompiuterinių kryžiažodžių sprendimas (kontrolinė grupė) [73]. Mokymai truko dvi valandas kartą per savaitę ir tęsèsi 5 savaites. Treniruočių efektas tirtas naudojantis tašku jungimo (angl. trail making test) testo A ir B dalimis. A dalyje dalyviai turi kuo greičiau ir tiksliau jungti skaičiais pažymėtus taškus, o B dalyje taškai yra pažymėti tiek skaičiais, tiek raidemis. Remiantis tyrimo išvadomis, dalyviai, kurie treniravosi prie kompiuterių namuose, po mokymų pagerino tiek A, tiek B dalies testų rezultatus, lyginant su kontroline grupe. Dalyviai, kurie dalyvavo treniruotėse, rengiamose mokymo centruose, pagerino tik A dalies rezultatus, lyginant su kontroline grupe. İrodymų apie šiame tyrime pasitelktų kognityvinių treniruočių įtaką ADRD ir MCI prevencijai nerasta.

Kito tyrimo $(n=84)$ metu dalyviai buvo suskirstyti i kontrolinę ir treniruočių grupes. 8 savaites (5 kartus per savaitę) vykdytos 20-25 minučių 6 sričių kognityvinès treniruotès (trumpalaikès ir ilgalaikès atminties, kalbos, erdvès, mąstymo ir skaičiavimo) [75]. Gauti tyrimo rezultatai, kad minètos treniruotès pagerino tik ilgalaikès atminties rezultatus. Lyginant kitus rezultatus su kontroline grupe, statistiškai reikšmingų skirtumų nerasta. 
Carretti su kolegomis atliktame tyrime [77] $(n=40)$ individualias kognityvines treniruotes gavę dalyviai lyginti su kontroline grupe. Treniruotese atmintis lavinta pasitelkiant garso ịrašus ir tekstą. Per dvi savaites dalyviai turejjo dalyvauti trijose kognityvinėse treniruotėse, kurių trukmė svyravo nuo 50 iki 70 minučių. Vertinant tyrimo rezultatus po 6 mènesių, nustatyta, kad dalyvių rezultatai, apdorojant garsinę informaciją, buvo geresni nei kontrolinès grupès. Po 6 ménesiu vertinant teksto apdorojimo gebẻjimus, reikšmingo skirtumo tarp grupių nerasta.

Klusmann su kolegomis [74] $(n=259)$ tyrime nagrinèjo grupés, kuriai paskirtos kompiuterizuotos kognityvinés treniruotès, ir kontrolinès grupès skirtumus. Treniruotès vykdavo apie 90 minučių 3 kartus per savaitę pusę metų. Treniruotès apėmè mokymąsi naudotis el. paštu ir internetu, fotografuoti ar redaguoti nuotraukas ir vaizdo ịrašus, žaisti žaidimus, apdoroti tekstus ir piešti. Vertinant rezultatus po 6 mẻnesių, kognityvinèse treniruotėse dalyvavusi grupè statistiškai reikšmingai pagerino trumpalaikès ir ilgalaikès atminties testų rezultatus, palyginti su kontroliniais dalyviais.

Paskutinis iš 6 tyrimų [78] ( $\mathrm{n}=461$, vidutinis dalyvių amžius - 73 metai) lygino grupinių ir individualių kognityvinių treniruočių rezultatus su kontroline grupe. Tiek grupinès, tiek individualios treniruotès vykdavo kartą per savaitę. Grupinių treniruočių metu dalyviai buvo skirstomi ị komandas, kurios buvo vertinamos pagal gebejimą priimti inovatyvius problemų sprendimus. Individualios treniruotės koncentravosi ties indukcinio mąstymo lavinimu. Treniruotės truko 16 savaičių. Atlikus kognityvinius testus po 8 mėnesių nuo tyrimo pradžios, nustatyta, kad, lyginant su kontroline grupe, tiek individualių, tiek grupinių treniruočių dalyviai rodè geresnius testų rezultatus toje srityje, kurioje buvo lavinami.

Penki tyrimai atlikti su asmenimis, turinčiais lengvą kognityvinį sutrikimą. Dalyvių skaičius svyravo nuo $19 \mathrm{iki}$ 223. Beveik visų tyrimų vienas pagrindinių kognityviniu treniruočių komponentų buvo atminties lavinimas, o tyrimai truko nuo 6 savaičių iki 6 mẻnesių. Kwok su kolegomis tyrime $(n=223$, vidutinis MMSE ịvertis - 26/30) vadovavosi ACTIVE tyrimo gairemis [79]. Kognityvinès treniruotės vykdavo apie 1,5 valandos kartą per savaitę, 12 savaičiu. Atliekant kognityvinius testus po metų nuo tyrimo pradžios, statistiškai reikšmingų skirtumų tarp tiriamosios ir kontrolinès grupių nerasta. Kitas tyrimas $(n=160)$ koncentravo treniruotes ị dèmesio sutelkimą, atmintį ir informacijos apdorojimą [80]. Dalyviams du kartus per savaitę, 5 savaites buvo rengiamos 90 minučių trukmès sesijos. Besibaigiant tyrimui, iš viso atlikta 11 kognityvinių testų, kurių nè vienas rezultatas nerodè reikšmingo skirtumo, lyginant su kontroline grupe.

Buschert su kolegomis ( $\mathrm{n}=24$, vidutinis MMSE iqvertis - 26/30) tyrimo dalyviams 6 mènesius rengè 2 valandu trukmès savaitinius ir socialinio ịsitraukimo mokymus. Tyrimo dalyviai rodė nedaug geresnius 1 iš 2 kognityvinių testų rezultatus, tačiau dẻl mažos imties yra sunku vertinti rezultatus.
Kitas tyrimas ( $n=22$, vidutinis MMSE ịvertis $-27 / 30)$ skyrẻ dalyviams kompiuterizuotas atmintį ir demesį lavinančias kognityvines treniruotes [81]. Treniruotės vykdavo dvi valandas per savaitę, 12 savaičiu. Kognityvinèse treniruotėse dalyvavę asmenys kognityvinių gebèjimų gerejjimą rodè 4 iš 9 kognityvinių testų. Paskutiniame tyrime $(\mathrm{n}=19$, vidutinis MMSE įvertis - 28/30) Rapp su kolegomis siekè nustatyti atmintị gerinančių kognityvinių treniruočiu įtaką asmenims, turintiems lengvą kognityvinị sutrikimą. Tyrimo dalyviai 6 savaites dalyvavo 2 valandu trukmès atminties treniruotese. Vertinant testų rezultatus po 6 mėnesių, reikšmingų skirtumų tarp grupių nerasta [82].

Dauguma žmonių, dalyvaujančių kognityvinėse treniruotėse, tikisi išvengti demencijos ar susijusių kognityvinių sutrikimų, tačiau, remdamiesi nagrinètais tyrimais, negalime daryti išvadų, kad kognityvinès treniruotès turi įtakos tikimybei susirgti ADRD ar MCI [72]. Dauguma tyrimų neminėjo rezultatų, susijusių su ADRD ar MCI, o pagrindiniai sèkmingų kognityvinių treniruočių rodikliai buvo kognityvinių testų rezultatai. Remiantis tyrimais, nustatyta, kad normalių kognityvinių asmenų rezultatai treniruotoje srityje buvo geresni sudalyvavus kognityvinese treniruotese. Dalyvių rezultatai kito tik tose srityse, kuriu treniruotėse jie dalyvavo [73, 76-78]. Reikšmingų skirtumų tarp kontrolinès ir tiriamosios grupių, kai tyrimo dalyviai turẻjo lengvą kognityvinị sutrikimą, nerasta. Remiantis esamais tyrimais, nepakanka įrodymų, kad kognityvinès treniruotés darytų įtaką ADRD ir MCI sergamumui ar padètų sulètinti kognityvinių gebẻjimų prastėjimą [72].

\section{IŠVADOS}

Vertinant nagrinètų 4 sisteminių analizių rezultatus, nerasta nẻ vieno efektyvaus gydymo metodo, užkertančio kelią ADRD ir MCI. Kai kurie nagrinèti tyrimai rodè teigiamus rezultatus - fizinis aktyvumas kartu su kitais riziką mažinančiais veiksniais FINGER tyrime lèmè $25 \%$ geresnius neuropsichologinių testų rezultatus nei kontrolinès grupés, o kognityvinių treniruočių tyrimai parodé, kad asmenų, turinčių normalius kognityvinius gebẻjimus, kognityvinių testų rezultatai gerejo toje srityje, kurioje tyrimo metu buvo treniruotasi. Deja, šie rezultatai neįrodo naudos, taikant minètus gydymo metodus ADRD ir MCI prevencijai. Medikamentinis gydymas ir maisto papildų vartojimas neịrodè savo naudos išlaikant ar pagerinant kognityvinius gebèjimus [83]. Dauguma tyrimų ne tik nenustatè nagrinejamų gydymo metodų teigiamo efekto Alzheimerio ligos ir susijusių demencijų prevencijai, bet ir daugeliu atvejų trūko įrodymų pagrindimo [83]. Vertingų išvadų trūkumas ịrodo Alzheimerio ligos ir demencijų rizikos veiksnių tyrimų komplikacijas ir apribojimus - atliekami sąlyginai trumpi tyrimai, nors liga atsiranda gerokai prieš pasireiškiant simptomams. Siekiant atlikti efektyvesnius tyrimus, turètuc būti atrinkti vidutinio amžiaus dalyviai ir iki jų senatvès stebimi riziką didinantys ar mažinantys veiksniai. Tačiau 
tokie tyrimai yra mažai tikètini dẻl sudètingos priežiūros, didelių sąnaudų ir galimai didelès dalyvių kaitos. Dèl įrodymų trūkumo, nei fizinis aktyvumas, nei medikamentinis gydymas, nei maisto papildų vartojimas, nei kognityvinès treniruotès nesumažina tikimybės susirgti ADRD ir MCI, naudojant šiuos metodus atskirai. Didžiausia tikimybè užkirsti kelią ADRD ar bent jau atidèti ligą yra kompleksiškas sveikos gyvensenos palaikymas - būti fiziškai aktyviam, nerūkyti, bendrauti ir būti socialiam, vengti veiksnių, didinančių riziką susirgti širdies ir kraujagyslių ligomis ir diabetu, palaikyti tinkamą mitybą ir sveiką svorị, taip pat koreguoti suprastėjusią klausą ar regą [83].

\section{Literatūra}

1. Prince M, Ali GC, Guerchet M, Prina AM, Albanese E, $\mathrm{Wu}$ YT. Recent global trends in the prevalence and incidence of dementia, and survival with dementia. Alzheimers Res Ther 2016; 8: 23. https://doi.org/10.1186/s13195-016-0188-8

2. Kelley A, McGarry K, Gorges R, Skinner J. The burden of health care costs for patients with dementia in the last 5 years of life. Ann Intern Med 2015; 163: 729-36. https://doi.org/ 10.7326/M15-0381

3. Prince M, Bryce R, Albanese E, Wimo A, Ribeiro W, Ferri CP. The global prevalence of dementia: a systematic review and metaanalysis. Alzheimers Dement 2013; 9: 63-75. https://doi.org/10.1016/j.jalz.2012.11.007

4. Albert MS, DeKosky ST, Dickson D, Dubois B, Feldman HH, Fox NC, et al. The diagnosis of mild cognitive impairment due to Alzheimer's disease: recommendations from the National Institute on Aging-Alzheimer's Association workgroups on diagnostic guidelines for Alzheimer's disease. Alzheimers Dement 2011; 7: 270-9. https://doi.org/ 10.1016/j.jalz.2011.03.008

5. Brasure M, Desai P, Davila H, Nelson VA, Calvert C, Jutkowitz E, et al. Physical activity interventions in preventing cognitive decline and Alzheimer-type dementia. A systematic review. Ann Intern Med 2018; 168(1): 30-9. https://doi.org/10.7326/M17-1528

6. Napoli N, Shah K, Waters DL, Sinacore DR, Qualls C, Villareal DT. Effect of weight loss, exercise, or both on cognition and quality of life in obese older adults. Am J Clin Nutr 2014; 100: 189-98. https://doi.org/10.3945/ajcn.113.082883

7. Sink KM, Espeland MA, Castro CM, Church T, Cohen R, Dodson JA, et al; LIFE Study Investigators. Effect of a 24-month physical activity intervention vs health education on cognitive outcomes in sedentary older adults: The LIFE randomized trial. JAMA 2015; 314: 781-90. https://doi.org/ 10.1001/jama.2015.9617

8. Taylor-Piliae RE, Newell KA, Cherin R, Lee MJ, King AC, Haskell WL. Effects of Tai Chi and Western exercise on physical and cognitive functioning in healthy communitydwelling older adults. J Aging Phys Act 2010; 18: 261-79. https://doi.org/10.1123/japa.18.3.261

9. Williamson JD, Espeland M, Kritchevsky SB, Newman AB, King AC, Pahor M, et al; LIFE Study Investigators. Changes in cognitive function in a randomized trial of physical activity: results of the lifestyle interventions and independence for elders pilot study. J Gerontol A Biol Sci Med Sci 2009; 64: 688-94. https://doi.org/10.1093/gerona/glp014

10. Antunes H, De Mello M, Santos-Galduro R, Galduro J, Lemos V, Tufik $S$, et al. Effects of a physical fitness program on memory and blood viscosity in sedentary elderly men. Braz J Med Biol Res 2015; 48: 805-12. https://doi.org/ $10.1590 / 1414-431$ X20154529

11. Lautenschlager NT, Cox KL, Flicker L, Foster JK, van Bockxmeer FM, Xiao J, et al. Effect of physical activity on cognitive function in older adults at risk for Alzheimer disease: a randomized trial. JAMA 2008; 300: 1027-37. https://doi.org/10.1001/jama.300.9.1027

12. Muscari A, Giannoni C, Pierpaoli L, Berzigotti A, Maietta P, Foschi E, et al. Chronic endurance exercise training prevents aging-related cognitive decline in healthy older adults: a randomized controlled trial. Int J Geriatr Psychiatry 2010; 25: 1055-64. https://doi.org/10.1002/gps.2462

13. Oken BS, Zajdel D, Kishiyama S, Flegal K, Dehen C, Haas M, et al. Randomized, controlled, six-month trial of yoga in healthy seniors: effects on cognition and quality of life. Altern Ther Health Med 2006; 12: 40-7.

14. Okumiya K, Matsubayashi K, Wada T, Kimura S, Doi Y, Ozawa T. Effects of exercise on neurobehavioral function in community-dwelling older people more than 75 years of age. J Am Geriatr Soc 1996; 44: 569-72. https://doi.org/10.1111/ j.1532-5415.1996.tb01444.x

15. Ruscheweyh R, Willemer C, Krüger K, Duning T, Warnecke T, Sommer J, et al. Physical activity and memory functions: an interventional study. Neurobiol Aging 2011; 32: 1304-19. https://doi.org/10.1016/j.neurobiolaging.2009.08.001

16. Cassilhas RC, Viana VA, Grassmann V, Santos RT, Santos $\mathrm{RF}$, Tufik $\mathrm{S}$, et al. The impact of resistance exercise on the cognitive function of the elderly. Med Sci Sports Exerc 2007; 39: 1401-7. https://doi.org/10.1249/mss.0b013e318060111f

17. Lachman ME, Neupert SD, Bertrand R, Jette AM. The effects of strength training on memory in older adults. J Aging Phys Act 2006; 14: 59-73. https://doi.org/10.1123/japa.14.1.59

18. van de Rest O, van der Zwaluw NL, Tieland M, Adam JJ, Hiddink GJ, van Loon LJ, et al. Effect of resistance-type exercise training with or without protein supplementation on cognitive functioning in frail and pre-frail elderly: secondary analysis of a randomized, double-blind, placebo-controlled trial. Mech Ageing Dev 2014; 136-137: 85-93. https://doi.org/10.1016/j.mad.2013.12.005

19. Martin CK, Anton SD, Han H, York-Crowe E, Redman LM, Ravussin E, et al. Examination of cognitive function during six months of calorie restriction: results of a randomized controlled trial. Rejuvenation Res 2007; 10: 179-90. https://doi.org/10.1089/rej.2006.0502

20. Tieland M, Borgonjen-Van den Berg KJ, van Loon LJ, de Groot LC. Dietary protein intake in community-dwelling, frail, and institutionalized elderly people: scope for improvement. Eur J Nutr 2012; 51: 173-9. https://doi.org/10.1007/ s00394-011-0203-6

21. Tieland M, Dirks ML, van der Zwaluw N, Verdijk LB, van de Rest O, de Groot LC, et al. Protein supplementation increases muscle mass gain during prolonged resistance-type exercise training in frail elderly people: a randomized, double-blind, placebo-controlled trial. J Am Med Dir Assoc 2012; 13: 713-9. https://doi.org/10.1016/j.jamda.2012.05.020

22. Hars M, Herrmann FR, Gold G, Rizzoli R, Trombetti A. Effect of music-based multitask training on cognition and mood in older adults. Age Ageing 2014; 43: 196-200. https://doi.org/10.1093/ageing/aft163

23. Ngandu T, Lehtisalo J, Solomon A, Levälahti E, Ahtiluoto S, Antikainen R, et al. A 2 year multidomain intervention of diet, exercise, cognitive training, and vascular risk monitoring versus control to prevent cognitive decline in at-risk el- 
derly people (FINGER): a randomised control trial. Lancet 2015; 385: 2255-63. https://doi.org/10.1016/ S0140-6736(15)60461-5

24. Fink HA, Jutkowitz E, McCarten JR, Hemmy LS, Butler M, Davila $\mathrm{H}$, et al. Pharmacologic interventions to prevent cognitive decline, mild cognitive impairment, and clinical Alzheimer-type dementia. A systematic review. Ann Intern Med 2018; 168(1): 39-53. https://doi.org/10.7326/M17-1529

25. Petersen RC, Thomas RG, Grundman M, Bennett D, Doody R, Ferris S, et al. Alzheimer's Disease Cooperative Study Group. Vitamin E and donepezil for the treatment of mild cognitive impairment. N Engl J Med 2005; 352(23): 2379-88. https://doi.org/10.1056/NEJMoa050151

26. Jack CJ, Petersen R, Grundman M, Jin S, Gamst A, Ward C, et al. Longitudinal MRI findings from the vitamin $\mathrm{E}$ and donepezil treatment study for MCI. Neurobiol Aging 2008; 29(9): 1285-95. https://doi.org/10.1016/j.neurobiolaging. 2007.03.004

27. Williamson JD, Launer LJ, Bryan RN, Coker LH, Lazar RM, Gerstein HC, et al; Action to Control Cardiovascular Risk in Diabetes Memory in Diabetes Investigators. Cognitive function and brain structure in persons with type 2 diabetes mellitus after intensive lowering of blood pressure and lipid levels: a randomized clinical trial. JAMA Intern Med 2014; 174: 324-33. https://doi.org/10.1001/jamainternmed. 2013.13656

28. Seaquist E, Miller M, Fonseca V, Ismail-Beigi F, Launer L, Punthakee Z. Effect of thiazolidinediones and insulin on cognitive outcomes in ACCORD-MIND. J Diabetes Complications 2013; 27: 485-91. https://doi.org/10.1016/ j.jdiacomp.2013.03.005

29. Launer LJ, Miller ME, Williamson JD, Lazar RM, Gerstein HC, Murray AM, et al; ACCORD MIND investigators. Effects of intensive glucose lowering on brain structure and function in people with type 2 diabetes (ACCORD MIND): a randomised open-label substudy. Lancet Neurol 2011; 10: 969-77. https://doi.org/10.1016/S1474-4422(11) 70188-0

30. Cukierman-Yaffe T, Bosch J, Diaz R, Dyal L, Hancu N, Hildebrandt P, et al; ORIGIN Investigators. Effects of basal insulin glargine and omega- 3 fatty acid on cognitive decline and probable cognitive impairment in people with dysglycaemia: a substudy of the ORIGIN trial. Lancet Diabetes Endocrinol 2014; 2: 562-72. https://doi.org/10.1016/ S2213-8587(14)70062-2

31. Hildreth KL, Van Pelt RE, Moreau KL, Grigsby J, Hoth KF, Pelak V, et al. Effects of pioglitazone or exercise in older adults with mild cognitive impairment and insulin resistance: a pilot study. Dement Geriatr Cogn Dis Extra 2015; 5: 51-63. https://doi.org/10.1159/000371509

32. Luchsinger JA, Perez T, Chang H, Mehta P, Steffener J, Pradabhan G, et al. Metformin in amnestic mild cognitive impairment: results of a pilot randomized placebo controlled clinical trial. J Alzheimers Dis 2016; 51: 501-14. https://doi.org/10.3233/JAD-150493

33. Breitner JC, Martin BK, Meinert CL. The suspension of treatments in ADAPT: concerns beyond the cardiovascular safety of celecoxib or naproxen. PLOS Clin Trials 2006; 1: e41. https://doi.org/10.1371/journal.pctr.0010041

34. ADAPT Research Group. Cardiovascular and cerebrovascular events in the randomized, controlled Alzheimer's Disease Anti-Inflammatory Prevention Trial (ADAPT). PLOS Clin Trials 2006; 1: e33. https://doi.org/ 10.1371/journal.pctr.0010033
35. Kang JH, Cook N, Manson J, Buring JE, Grodstein F. Low dose aspirin and cognitive function in the women's health study cognitive cohort. BMJ 2007; 334: 987. https://doi.org/ 10.1136/bmj.39166.597836.BE

36. Yaffe K, Krueger K, Cummings SR, Blackwell T, Henderson VW, Sarkar S, et al. Effect of raloxifene on prevention of dementia and cognitive impairment in older women: the Multiple Outcomes of Raloxifene Evaluation (MORE) randomized trial. Am J Psychiatry 2005; 162: 683-90. https://doi.org/10.1176/appi.ajp.162.4.683

37. Yaffe K, Krueger K, Sarkar S, Grady D, Barrett-Connor E, Cox DA, et al; Multiple Outcomes of Raloxifene Evaluation Investigators. Cognitive function in postmenopausal women treated with raloxifene. N Engl J Med 2001; 344: 1207-13. https://doi.org/10.1056/NEJM200104193441604

38. Nickelsen T, Lufkin EG, Riggs BL, Cox DA, Crook TH. Raloxifene hydrochloride, a selective estrogen receptor modulator: safety assessment of effects on cognitive function and mood in postmenopausal women. Psychoneuroendocrinology 1999; 24: 115-28. https://doi.org/10.1016/S0306-4530 (98)00041-9

39. Resnick SM, Matsumoto AM, Stephens-Shields AJ, Ellenberg SS, Gill TM, Shumaker SA, et al. Testosterone treatment and cognitive function in older men with low testosterone and age-associated memory impairment. JAMA 2017; 317: 717-27. https://doi.org/10.1001/jama.2016.21044

40. Qato DM, Wilder J, Schumm LP, Gillet V, Alexander GC. Changes in prescription and over-the-counter medication and dietary supplement use among older adults in the United States, 2005 vs 2011. JAMA Intern Med 2016; 176: 473-82. https://doi.org/10.1001/jamainternmed.2015.8581

41. Butler M, Nelson VA, Davila H, Ratner E, Fink HA, Hemmy LS, et al. Over-the-counter supplement interventions to prevent cognitive decline, mild cognitive impairment, and clinical Alzheimer-type dementia. A systematic review. Ann Intern Med 2018; 168(1): 52-63. https://doi.org/ 10.7326/M17-1530

42. Yurko-Mauro K, McCarthy D, Rom D, Nelson EB, Ryan AS, Blackwell A, et al; MIDAS Investigators. Beneficial effects of docosahexaenoic acid on cognition in age-related cognitive decline. Alzheimers Dement 2010; 6: 456-64. https://doi.org/10.1016/j.jalz.2010.01.013

43. Witte AV, Kerti L, Hermannstädter HM, Fiebach JB, Schreiber SJ, Schuchardt JP, et al. Long-chain omega-3 fatty acids improve brain function and structure in older adults. Cereb Cortex 2014; 24: 3059-68. https://doi.org/10.1093/ cercor/bht163

44. Lee LK, Shahar S, Chin AV, Yusoff NA. Docosahexaenoic acid-concentrated fish oil supplementation in subjects with mild cognitive impairment (MCI): a 12-month randomised, double-blind, placebo-controlled trial. Psychopharmacology (Berl) 2013; 225: 605-12. https://doi.org/10.1007/ s00213-012-2848-0

45. Gleason CE, Carlsson CM, Barnet JH, Meade SA, Setchell KD, Atwood CS, et al. A preliminary study of the safety, feasibility and cognitive efficacy of soy isoflavone supplements in older men and women. Age Ageing 2009; 38: 86-93. https://doi.org/10.1093/ageing/afn227

46. Ho SC, Chan AS, Ho YP, So EK, Sham A, Zee B, et al. Effects of soy isoflavone supplementation on cognitive function in Chinese postmenopausal women: a double-blind, randomized, controlled trial. Menopause 2007; 14: 489-99. https://doi.org/10.1097/GME.0b013e31802c4f4f 
47. Kato-Kataoka A, Sakai M, Ebina R, Nonaka C, Asano T, Miyamori T. Soybean-derived phosphatidylserine improves memory function of the elderly Japanese subjects with memory complaints. J Clin Biochem Nutr 2010; 47: 246-55. https://doi.org/10.3164/jcbn.10-62

48. Kritz-Silverstein D, Von Mühlen D, Barrett-Connor E, Bressel MA. Isoflavones and cognitive function in older women: the SOy and Postmenopausal Health In Aging (SOPHIA) Study. Menopause 2003; 10: 196-202. https://doi.org/10.1097/00042192-200310030-00004

49. DeKosky ST, Williamson JD, Fitzpatrick AL, Kronmal RA, Ives DG, Saxton JA, et al; Ginkgo Evaluation of Memory (GEM) Study Investigators. Ginkgo biloba for prevention of dementia: a randomized controlled trial. JAMA 2008; 300: 2253-62. https://doi.org/10.1001/jama.2008.683

50. Dodge HH, Zitzelberger T, Oken BS, Howieson D, Kaye J. A randomized placebo-controlled trial of Ginkgo biloba for the prevention of cognitive decline. Neurology 2008; 70: 1809-17. https://doi.org/10.1212/01.wnl.0000303814.13509.db

51. Snitz BE, O'Meara ES, Carlson MC, Arnold AM, Ives DG, Rapp SR, et al; Ginkgo Evaluation of Memory (GEM) Study Investigators. Ginkgo biloba for preventing cognitive decline in older adults: a randomized trial. JAMA 2009; 302: 2663-70. https://doi.org/10.1001/jama.2009.1913

52. Vellas B, Coley N, Ousset PJ, Berrut G, Dartigues JF, Dubois B, et al; GuidAge Study Group. Long-term use of standardised Ginkgo biloba extract for the prevention of Alzheimer's disease (GuidAge): a randomised placebo-controlled trial. Lancet Neurol 2012; 11: 851-9. https://doi.org/ 10.1016/S1474-4422(12)70206-5

53. Gavrilova SI, Preuss UW, Wong JW, Hoerr R, Kaschel R, Bachinskaya N; GIMCIPlus Study Group. Efficacy and safety of Ginkgo biloba extract EGb 761 in mild cognitive impairment with neuropsychiatric symptoms: a randomized, placebo-controlled, double-blind, multi-center trial. Int $\mathrm{J}$ Geriatr Psychiatry 2014; 29: 1087-95. https://doi.org/ 10.1002/gps.4103

54. Durga J, van Boxtel MP, Schouten EG, Kok FJ, Jolles J, Katan MB, et al. Effect of 3-year folic acid supplementation on cognitive function in older adults in the FACIT trial: a randomised, double blind, controlled trial. Lancet 2007; 369: 208-16 https://doi.org/10.1016/S0140-6736(07)60109-3

55. Walker JG, Batterham PJ, Mackinnon AJ, Jorm AF, Hickie I, Fenech M, et al. Oral folic acid and vitamin B-12 supplementation to prevent cognitive decline in community-dwelling older adults with depressive symptoms - the Beyond Ageing Project: a randomized controlled trial. Am J Clin Nutr 2012; 95: 194-203. https://doi.org/10.3945/ ajcn.110.007799

56. van der Zwaluw NL, Dhonukshe-Rutten RA, van Wijngaarden JP, Brouwer-Brolsma EM, van de Rest O, In 't Veld PH, et al. Results of 2-year vitamin B treatment on cognitive performance: secondary data from an RCT. Neurology 2014; 83: 2158-66. https://doi.org/10.1212/ WNL.0000000000001050

57. Andreeva V, Kesse-Guyot E, Barberger-Gateau P, Fezeu L, Hercberg S, Galan P. Cognitive function after supplementation with B vitamins and long-chain omega-3 fatty acids: ancillary findings from the SU.FOL.OM3 randomized trial. Am J Clin Nutr 2011; 94: 278-86. https://doi.org/10.3945/ajcn.110.006320

58. McMahon JA, Green TJ, Skeaff CM, Knight RG, Mann JI, Williams SM. A controlled trial of homocysteine lowering and cognitive performance. N Engl J Med 2006; 354: 2764-72. https://doi.org/10.1056/NEJMoa054025

59. Smith AD, Smith SM, de Jager CA, Whitbread P, Johnston C, Agacinski G, et al. Homocysteine-lowering by B vitamins slows the rate of accelerated brain atrophy in mild cognitive impairment: a randomized controlled trial. PLoS One 2010; 5: e12244. https://doi.org/10.1371/journal.pone.0012244

60. de Jager CA, Oulhaj A, Jacoby R, Refsum H, Smith AD. Cognitive and clinical outcomes of homocysteine-lowering B-vitamin treatment in mild cognitive impairment: a randomized controlled trial. Int J Geriatr Psychiatry 2012; 27: 592-600. https://doi.org/10.1002/gps.2758

61. Douaud G, Refsum H, de Jager CA, Jacoby R, Nichols TE, Smith SM, et al. Preventing Alzheimer's disease-related gray matter atrophy by B-vitamin treatment. Proc Natl Acad Sci U S A 2013; 110: 9523-8. https://doi.org/10.1073/ pnas. 1301816110

62. Oulhaj A, Jernerén F, Refsum H, Smith AD, de Jager CA. Omega-3 fatty acid status enhances the prevention of cognitive decline by B vitamins in mild cognitive impairment. J Alzheimers Dis 2016; 50: 547-57. https://doi.org/10.3233/ JAD-150777

63. Rossom RC, Espeland MA, Manson JE, Dysken MW, Johnson $\mathrm{KC}$, Lane DS, et al. Calcium and vitamin D supplementation and cognitive impairment in the Women's Health Initiative. J Am Geriatr Soc 2012; 60: 2197-205. https://doi.org/10.1111/jgs. 12032

64. Kryscio RJ, Abner EL, Caban-Holt A, Lovell M, Goodman P, Darke AK, et al. Association of antioxidant supplement use and dementia in the Prevention of Alzheimer's Disease by Vitamin E and Selenium Trial (PREADViSE). JAMA Neurol 2017; 74: 567-73. https://doi.org/10.1001/ jamaneurol.2016.5778

65. Kang JH, Cook NR, Manson JE, Buring JE, Albert CM, Grodstein F. Vitamin E, vitamin C, beta carotene, and cognitive function among women with or at risk of cardiovascular disease: the Women's Antioxidant and Cardiovascular Study. Circulation 2009; 119: 2772-80. https://doi.org/ 10.1161/CIRCULATIONAHA.108.816900

66. Kang JH, Cook N, Manson J, Buring JE, Grodstein F. A randomized trial of vitamin $\mathrm{E}$ supplementation and cognitive function in women. Arch Intern Med 2006; 166: 2462-8. https://doi.org/10.1001/archinte.166.22.2462

67. Wolters M, Hickstein M, Flintermann A, Tewes U, Hahn A. Cognitive performance in relation to vitamin status in healthy elderly German women - the effect of 6-month multivitamin supplementation. Prev Med 2005; 41: 253-9. https://doi.org/ 10.1016/j.ypmed.2004.11.007

68. Heart Protection Study Collaborative Group. MRC/BHF Heart Protection Study of antioxidant vitamin supplementation in 20,536 high-risk individuals: a randomised placebo-controlled trial. Lancet 2002; 360: 23-33. https://doi.org/10.1016/S0140-6736(02)09328-5

69. Grodstein F, O'Brien J, Kang JH, Dushkes R, Cook NR, Okereke $\mathrm{O}$, et al. Long-term multivitamin supplementation and cognitive function in men: a randomized trial. Ann Intern Med 2013; 159: 806-14. https://doi.org/10.7326/ 0003-4819-159-12-201312170-00006

70. McNeill G, Avenell A, Campbell MK, Cook JA, Hannaford PC, Kilonzo MM, et al. Effect of multivitamin and multimineral supplementation on cognitive function in men and women aged 65 years and over: a randomised controlled trial. Nutr J 2007; 6: 10. https://doi.org/10.1186/ 1475-2891-6-10 
71. Naeini AM, Elmadfa I, Djazayery A, Barekatain M, Ghazvini MR, Djalali M, et al. The effect of antioxidant vitamins $\mathrm{E}$ and $\mathrm{C}$ on cognitive performance of the elderly with mild cognitive impairment in Isfahan, Iran: a double-blind, randomized, placebo-controlled trial. Eur J Nutr 2014; 53: 1255-62. https://doi.org/10.1007/s00394-013-0628-1

72. Butler M, McCreedy E, Nelson VA, Desai P, Ratner E, Fink HA, et al. Does cognitive training prevent cognitive decline? A systematic review. Ann Intern Med 2018; 168(1): 63-9. https://doi.org/10.7326/M17-1531

73. Wolinsky FD, Vander Weg MW, Howren MB, Jones MP, Dotson MM. A randomized controlled trial of cognitive training using a visual speed of processing intervention in middle aged and older adults. PLoS One 2013; 8: e61624. https://doi.org/10.1371/journal.pone.0061624

74. Klusmann V, Evers A, Schwarzer R, Schlattmann P, Reischies FM, Heuser I, et al. Complex mental and physical activity in older women and cognitive performance: a 6-month randomized controlled trial. J Gerontol A Biol Sci Med Sci 2010; 65: 680-8. https://doi.org/10.1093/gerona/ glq053

75. Miller KJ, Dye RV, Kim J, Jennings JL, O’Toole E, Wong J, et al. Effect of a computerized brain exercise program on cognitive performance in older adults. Am J Geriatr Psychiatry 2013; 21: 655-63. https://doi.org/10.1016/ j.jagp.2013.01.077

76. Ball K, Berch DB, Helmers KF, Jobe JB, Leveck MD, Marsiske M, et al; Advanced Cognitive Training for Independent and Vital Elderly Study Group. Effects of cognitive training interventions with older adults: a randomized controlled trial. JAMA 2002; 288: 2271-81. https://doi.org/ 10.1001/jama.288.18.2271

77. Carretti B, Borella E, Zavagnin M, de Beni R. Gains in language comprehension relating to working memory training in healthy older adults. Int J Geriatr Psychiatry 2013; 28: 539-46. https://doi.org/10.1002/gps.3859

78. Stine-Morrow EA, Payne BR, Roberts BW, Kramer AF, Morrow DG, Payne L, et al. Training versus engagement as paths to cognitive enrichment with aging. Psychol Aging 2014; 29: 891-906. https://doi.org/10.1037/a0038244

79. Kwok TC, Bai X, Li JC, Ho FK, Lee TM. Effectiveness of cognitive training in Chinese older people with subjective cognitive complaints: a randomized placebo-controlled trial. Int J Geriatr Psychiatry 2013; 28: 208-15. https://doi.org/ $10.1002 /$ gps.3812

80. Vidovich MR, Lautenschlager NT, Flicker L, Clare L, McCaul K, Almeida OP. The PACE study: a randomized clinical trial of cognitive activity strategy training for older people with mild cognitive impairment. Am J Geriatr Psychiatry 2015; 23: 360-72. https://doi.org/10.1016/ j.jagp.2014.04.002

81. Herrera C, Chambon C, Michel BF, Paban V, AlescioLautier B. Positive effects of computer-based cognitive training in adults with mild cognitive impairment. Neuropsychologia 2012; 50: 1871-81. https://doi.org/10.1016/ j.neuropsychologia.2012.04.012

82. Rapp S, Brenes G, Marsh AP. Memory enhancement training for older adults with mild cognitive impairment: a preliminary study. Aging Ment Health 2002; 6: 5-11. https://doi.org/ 10.1080/13607860120101077

83. Larson EB. Prevention of late-life dementia: no magic bullet. Ann Intern Med 2018; 168(1): 77-9. https://doi.org/10.7326/ M17-3026

\section{G. Navickaitė}

\section{THE EFFECT OF PHYSICAL ACTIVITY, PHARMACOLOGIC INTERVENTIONS, OVER-THE-COUNTER SUPPLEMENTS AND COGNITIVE TRAINING IN PREVENTING ALZHEIMER'S DISEASE, MILD COGNITIVE IMPAIRMENT AND RELATED DEMENTIAS: AN OVERVIEW}

\section{Summary}

Due to the aging population, the incidence of Alzheimer's disease and related dementias (ADRD) and mild cognitive impairment (MCI) is likely to increase. Currently, there is no hard evidence neither on effective methods of their treatment nor on even prevention. However, the potential benefits of physical activity, pharmacologic interventions, over-the-counter supplements and cognitive training are publicly discussed. Nonetheless, positive effects of such methods are not based on the evidence obtained from the related studies. This article presents an overview of the results of systematic analyses of the four methods - physical activity, pharmacologic interventions, over-the-counter supplements and cognitive training - and their effect in preventing ADRD and MCI.

Keywords: Alzheimer's disease, dementia, mild cognitive impairment, physical activity, pharmacologic intervention, over-the-counter supplements, cognitive training.

Gauta:

Priimta spaudai:

20180216 20180227 